\title{
Impacts of El Niño Climate Anomaly on Irrigation Scheduling of Maize Crop Using Budget Models under Tropical Climate Conditions
}

\author{
DOI: 10.18196/pt.2018.080.49-61
}

\author{
Momon Sodik Imanudin ${ }^{1 *}$, Bakri $^{1}$, Karimuddin $\mathrm{Y}^{1}$, and P. Ratmini ${ }^{2}$ \\ ${ }^{1}$ Soil Science Department, Faculty of Agriculture, Sriwijaya University, Kampus Unsri Inderalaya \\ Jl. Palembang Prabumulih Km 32, Palembang, Indonesia, 30662 \\ ${ }^{2}$ Assessment Institutes for Agricultural Technology of South Sumatra \\ * Corresponding author, email: momon2001kh@yahoo.com.hk
}

\begin{abstract}
The research aims to calculate the water requirement and irrigation interval of maize crop as well as to design water-efficient irrigation application system. The study was conducted on dry land of Palembang city of South Sumatra. The indicator crop used in this study was maize. Daily climate data were taken from Sultan Mahmud Badarudin and Kenten station. The research applied survey method, laboratory analysis, computer simulation and irrigation design. The calculation of water crop deficiency was done using empirical approach by multiplying the potential evapotranspiration value by crop coefficient. Soil water retention characteristic was recorded based on the calculation of the length of water available to plants. Daily rainfall in the field was recorded as water input other than water from irrigation. The combination of soil, climate and plant physiological properties (Agro-pedo-climatic) will result in a water irrigation system in a region. Water balance analysis was developed by the help of computer model (BUDGET model). The result of computer model analysis shows that maize crop in rainy season does not require irrigation. While for the transition period (March-May), irrigation is required for the flowering phase with a total water requirement of $76.5 \mathrm{~mm}$. During dry season (May-July), irrigation is required with water requirement of $198 \mathrm{~mm}$. Irrigation scheduling is set up 9 times with intervals every 7 days at the beginning of growth and 10 days at the middle and end. While the testing under dry climate conditions (EI Niño) using rainfall data in 2015 indicates irrigation should be given since March and during planting period (May-August 2015) the irrigation should be applied 12 times with intervals every 5 days at the initial stage and 10 days during vegetative stage..
\end{abstract}

Keywords: Irrigation scheduling, Maize crop, Agropedoclimatic data, Budget model

\section{ABSTRAK}

Penelitian ini bertujuan untuk menghitung kebutuhan air dan interval irigasi tanaman jagung serta untuk merancang sistem aplikasi irigasi hemat air. Penelitian dilakukan di lahan kering kota Palembang, Sumatera Selatan. Tanaman indikator yang digunakan dalam penelitian ini adalah jagung. Data iklim harian diambil dari Sultan Mahmud Badarudin dan stasiun Kenten. Penelitian ini menggunakan metode survei, analisis laboratorium, simulasi komputer dan desain irigasi. Perhitungan defisiensi tanaman air dilakukan dengan menggunakan pendekatan empiris dengan mengalikan nilai evapotranspirasi potensial dengan koefisien tanaman. Karakteristik retensi air tanah dicatat berdasarkan perhitungan panjang air yang tersedia untuk tanaman. Curah hujan harian di lapangan dicatat sebagai masukan air selain air dari irigasi. Kombinasi tanah, iklim dan sifat fisiologis tanaman (Agro-pedo-climatic) akan menghasilkan sistem irigasi air di suatu wilayah. Analisis neraca air dikembangkan dengan bantuan model komputer (model BUDGET). Hasil analisis model komputer menunjukkan bahwa tanaman jagung di musim hujan tidak memerlukan irigasi. Sementara untuk periode transisi (Maret-Mei), irigasi diperlukan untuk fase pembungaan dengan total kebutuhan air 76,5 mm. Selama musim kemarau (Mei-Juli), irigasi diperlukan dengan kebutuhan air sebesar 198 mm. Penjadwalan irigasi diatur 9 kali dengan interval setiap 7 hari pada awal pertumbuhan dan 10 hari di tengah dan akhir. Sementara pengujian dalam kondisi iklim kering (El Niño) menggunakan data curah hujan pada tahun 2015 menunjukkan irigasi harus diberikan sejak Maret dan selama periode tanam (Mei-Agustus 2015) irigasi harus diterapkan 12 kali dengan interval setiap 5 hari pada tahap awal dan 10 hari selama tahap vegetatif.

Kata Kunci: Penjadwalan irigasi, Jagung, Agropedoclimatic data, Model anggaran

\section{INTRODUCTION}

The need for domestic maize crop is continuously increasing. So far, the demand is quite high, especially for feed (poultry) ranging from $45-55 \%$, so it is predicted that the national animal feed industry requires as much as 3.5 million tons of maize crop annually. The gap between imports and national production capability is still wide, although national production is also increasing. Therefore, the potential of domestic maize crop production should be improved. The problem is that the plants need water continuously to grow and to produce yield, while water supply from rain 
is not available all month long. There are several months where farmers can't cultivate crops due to water deficit. This condition requires an effort to provide water from the outside through irrigation applications (Yoo et al., 2008).

Hook et al., (2001), states that irrigation scheduling is an important part in the preparation of water management strategies. Irrigation scheduling concerns on how much water is given and when it is given. Kumar et al. (2017) added that proper irrigation scheduling could create energy efficiency and support the green agriculture movement and green energy. The amount of water given is very dependent on the ability of the soil to store water and the ability of plants to absorb water in the plant zone. To be more effective and efficient in irrigation applications in dry land, micro irrigation technology is very appropriate (Imanudin et al., 1997). This micro irrigation applies irrigation given right in the plant's roots zones. Method of water delivery can be applied through drip irrigation, drip, bulk (micro spray) and mini-sprinkler.

Micro irrigation is a small water supply system for crops using low. In order to establish a micro irrigation system, it is necessary to get information about water source in the field and the distribution technology to be provided for water to plant root zone. Water balance is an interaction between land components consisting of soil, water (climate and hydrology) and plants (Imanudin, 2001, Imanudin and Tambas, 2002). Thus, land variable is very important as a growing medium that will determine the amount of water that can be stored and distributed. In this context, the important physical properties of soil necessarily known are texture, porosity, permeability, weight of content, infiltration and soil moisture characteristic curve (Imanudin and Susanto 1995).

Water management planning for dry land crops covers when and where cultivation is done, how much water is needed, and when irrigation should be provided. The permafrost in the tropics lies in the limitations of the data. This information has not been available until now, so farmers often experience failure of crop cultivation because the plants experience water limitations during the growth period. The recommendation of irrigation scheduling system will be different for the types of plant, soil and local climatic conditions. Therefore, good planning should include land-climatic data components and plant aspects (Imandin and Tambas, 2002; Imanudin and Susanto, 2005). To facilitate farmers in irrigation applications, it is necessary to have practical guidance in the form of irrigation scheduling cards (Imanudin and Bakri 2012). The preparation of irrigation scheduling should be carried out on two different climatic conditions with several alternative soil types (Imanudin and Susanto, 2005). Through the help of computer model (BUDGET), then prediction of ground water level dynamics in plant root zone can be determined and then the irrigation scheduling system can be developed (Kenjabaev, 2013). Estimation of soil moisture content is an important part in irrigation planning. The main objective of irrigation is to ensure soil moisture conditions to meet the needs of plant evapotranspiration (Dhotre et al., 2017).

From the potentials and constraints previously mentioned, it is necessary to draft irrigation scheduling for maize crops in two climatic conditions (dry and wet) in South Sumatra. It is expected that from the computer simulation the efficiency of irrigation will be obtained since the water is given in the right amount and time, so that water saving efforts can be achieved. The study aims to determine the water requirements of maize crops and to make irrigation scheduling in sandy clay soil due to the influence of El Niño (dry) and La Niña (Wet) climate anomaly. 


\section{MATERIALS AND METHODS}

This research was conducted at Soil Physics Laboratory of Soil Department, Faculty of Agriculture, Sriwijaya University. The type of soil texture used in this study is sandy clay. The duration of the study is one year in which computer simulation techniques utilize daily climate data from January to December 2016 for wet conditions and that from January to December 2015 for dry conditions as a result of El Niño.

The materials used in this research were data of climate, rainfall, and soil and the equipment used were the sample ring and soil drill. While data analysis of water balance was conducted using Excel computer spread sheet and computer model (BUDGET) (Raes, 2002).

The calculation of crop's water requirement was done using empirical approach by multiplying potential evapotraspiration value by plant coefficient. Soil water retention characteristics were made the basis for calculating the length of water available to plants. Daily rainfall in the field was recorded as water input other than water from irrigation (Imanudin and Susanto, 1995). The combination of soil, climate and plant physiological properties (Agro-pedo-climatic) will result in irrigation system in one region (Imanudin and Susanto, 2005). The research steps can be seen in Figure 1.

Groundwater retention was calculated using the pedotransfer function approach. The calculation steps are as follows (Imanudin and Tambas, 2002).

\section{Estimation of groundwater retention}

- Saturated groundwater status

$\theta_{\text {sat }}=0.332-7.251 * \mathbb{0}-4 \%$ sand $)+0.1276 \log _{0}$ \% clay $)[1]$

where: $\theta_{\text {sat }}$ : saturated groundwater content $\left(\mathrm{m}^{3} /\right.$ $\left.\mathrm{m}^{3}\right) ; \%$ sand : \% sand fraction (mass\%); \% clay: clay fraction (mass\%).
- Groundwater status field capacity

$\theta_{\sigma=-0 . R a}=0.4118-0.0030 \%$ sand $)+0.0023 \%$ clay $)+0.0317 \%$ Q $)$

$\theta_{\omega=-3 \mathrm{kPa}}=0.2576-0.0020 \%$ sand $)+0.0036 \%$ clay $)+0.0299 \%$ (d) )

where: $\theta_{\sigma=-1 \mathrm{kPa}}$ : groundwater content $\left(\mathrm{m}^{3} / \mathrm{m}^{3}\right)$ for potential matrix

$-10 \mathrm{kPa} ; \theta_{\sigma=-3} \mathrm{kPa}$ : groundwater content $\left(\mathrm{m}^{3} / \mathrm{m}^{3}\right)$ for potential matrix

$-33 \mathrm{kPa}$ and \% OM; percentage of organic matter content (\% mass).

- Groundwater status at permanent wilting point

$\theta_{\text {Wy }}=0.0260+0.0050 \%$ clay $)+0.0158 \%$ Or $)[4]$

Where: \% clay: the percentage of clay fraction, $\%$ OM: the percentage of organic matter content (\% mass).

Calculation of water available to plant and readily available water

Water available to plants is water that is ready and easy to be absorbed by plant roots. This available water is water content that is in the condition of field capacity and permanent wilt point.

Available water $(\%$ volume $)=($ water content at field capacity $\theta_{\sigma=-1 \mathrm{kPa}}$ - water content at permanent wilting point $\theta \mathbb{W} \quad$ )\% volume

For irrigation purposes, the plants should be watered before the groundwater level reaches permanent wilting point. This means that water is provided before the water is available. For most plants irrigation is given after $75 \%$ of available water is running out (Yoo et al., 2008). For plants 
that are sensitive to drought, water is given when $50 \%$ of available water is running out. Analysis of crop water requirement, ground water balance, and design of plant irrigation scheduling

Water requirements of a plant can be defined as the amount of water required to meet the water loss through evapotranspiration (ET-plant) of healthy plant which is grown on a large plot of land with no soil constraints (soil moisture and soil fertility constraint) achieving potential full production under certain environmental conditions (Doorenbus and Pruit, 1986; Zotareli et al., 2009).

The first step in calculating crop water requirement is calculating the potential evapotranspiration value. The potential evapotranspiration value (ETo) is calculated using Penman-monteith's equation as follows:

$$
\lambda \boldsymbol{E}=\frac{\Delta\left(R_{n}-G\right)+\rho_{a} C_{p} \frac{\left(e_{s-} e_{a}\right)}{r_{a}}}{\Delta+\gamma\left[1+\frac{r_{s}}{r_{a}}\right]}
$$

where $\mathrm{Rn}$ is the net radiation value, $\mathrm{G}$ is the value of ground heat flow, (es - ea) shows the gas deficit pressure in air, $\rho_{a}$ is air density at constant pressure, $\mathrm{cp}$ is specific heat value in air, $\Delta$ is the slope between the saturated vapor pressure corresponding to the temperature, $\gamma$ is the constant value of physicrometry, $r$ is sun radiation factor that has been corrected, and $r a$ is the value of solar radiation where the value is influenced by the latitude of a region.

The effect of plant characteristics on crop water requirements is given by the plant coefficient $(\mathrm{kc})$ which expresses the relationship between ETo and ET $\operatorname{crop}($ ETtan $==$ ETo $)$. Kc values vary with plant species, plant growth phase, growing season, and weather conditions. The value of plant coefficient can be seen in Table 8. Etc water requirements can be calculated based on the equation below:

$$
\text { ET-plant }(\mathrm{ETc})=\mathrm{kc} \cdot \text { ETo }
$$

Water balance in the field is to show how much water is added and released as well as water which can be stored in the soil for a period of time (Hillel, 1980). Therefore, the water balance in the soil for a given period of time $(\Delta t)$ can be expressed in the equation below:

$$
\Delta S_{L}=\mathrm{P}+\mathrm{I}-\mathrm{ETa}-\mathrm{QL}-\mathrm{R}
$$

Where is the change of water storage from the soil surface to a certain depth of L (root depth); P is rainfall; I is irrigation; ETa is the actual evaporation; QL is the amount of water lost by drainage as a function of ground flux integration within the boundary area (L); and $\mathrm{R}$ is the surface flow.

The first step to determine irrigation scheduling is counting water available to the plant first. Equation 14 is to show how to calculate the value of available water.

Available water $(\%$ volume $)=($ Water content at field capacity $\theta_{\bar{\sigma}=-\mathrm{D} \mathrm{kPa}}$ - water content at permanent wilting point $\theta \mathbb{W} \quad$ )\% volume

Water that is still able to be absorbed by plants from available water is known as readily available water. In the irrigation application plan, irrigation scheduling will be arranged for the condition where $40 \%$ of available water is running out.

Readily available water $=0,4 \mathrm{x}$ available water (\% volume)

[10] 


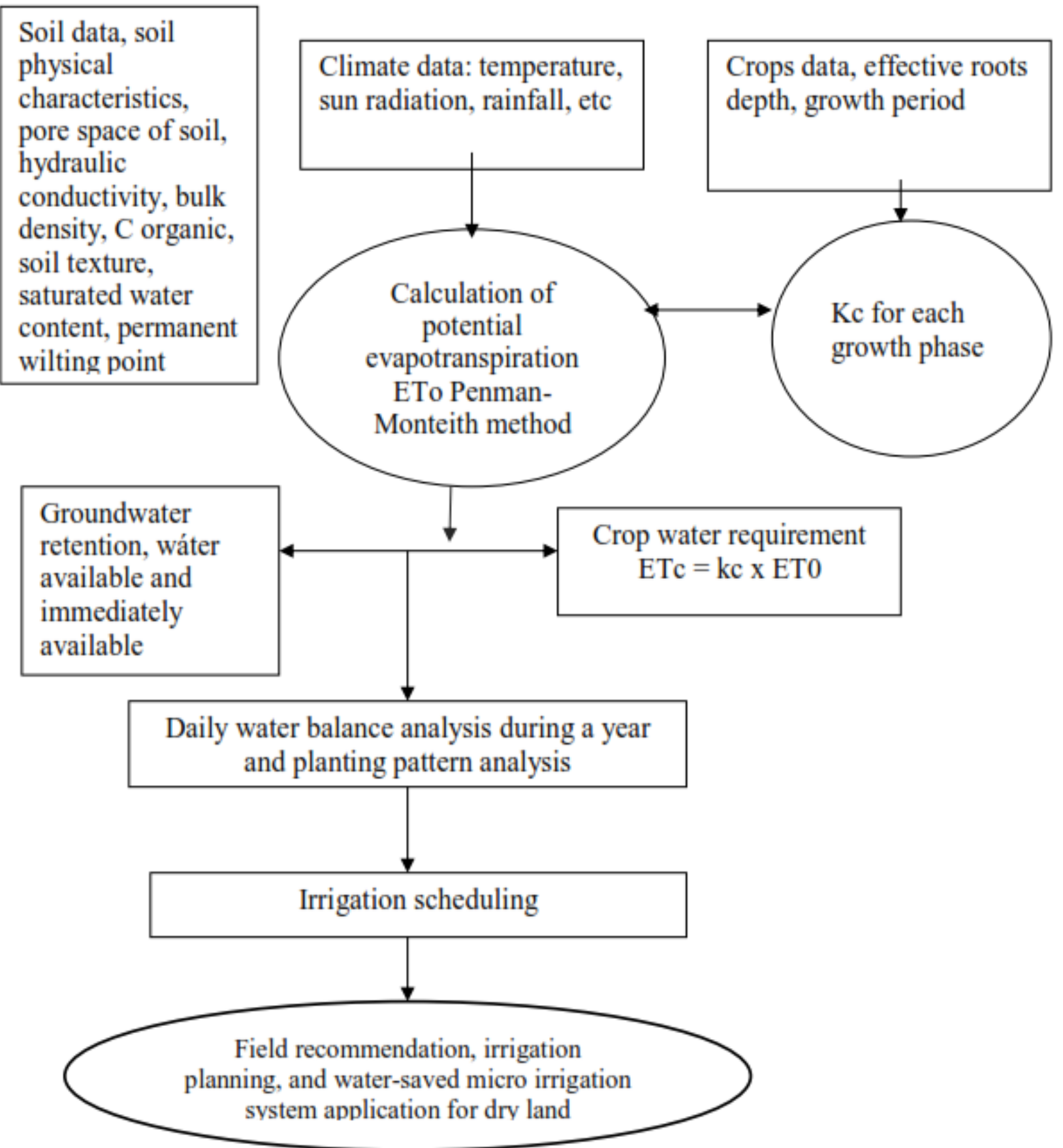

Figure 1. Chartflow of Research Steps (Bakri and Imanudin, 2012) 


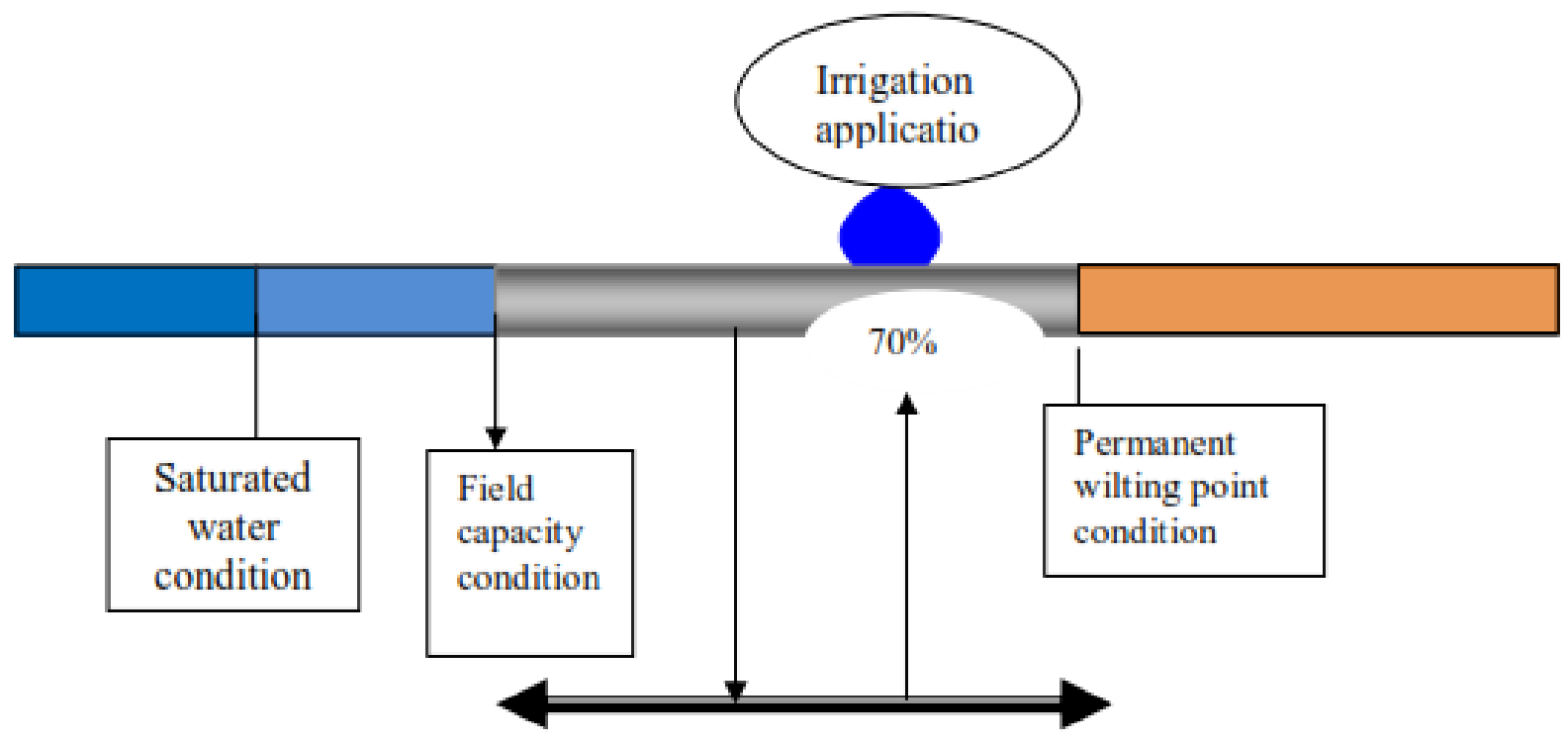

Available water

Figure 2. Ilustration of irrigation applicartion concept as the basis of irrigation scheduling (Bakri and Imanudin, 2012)

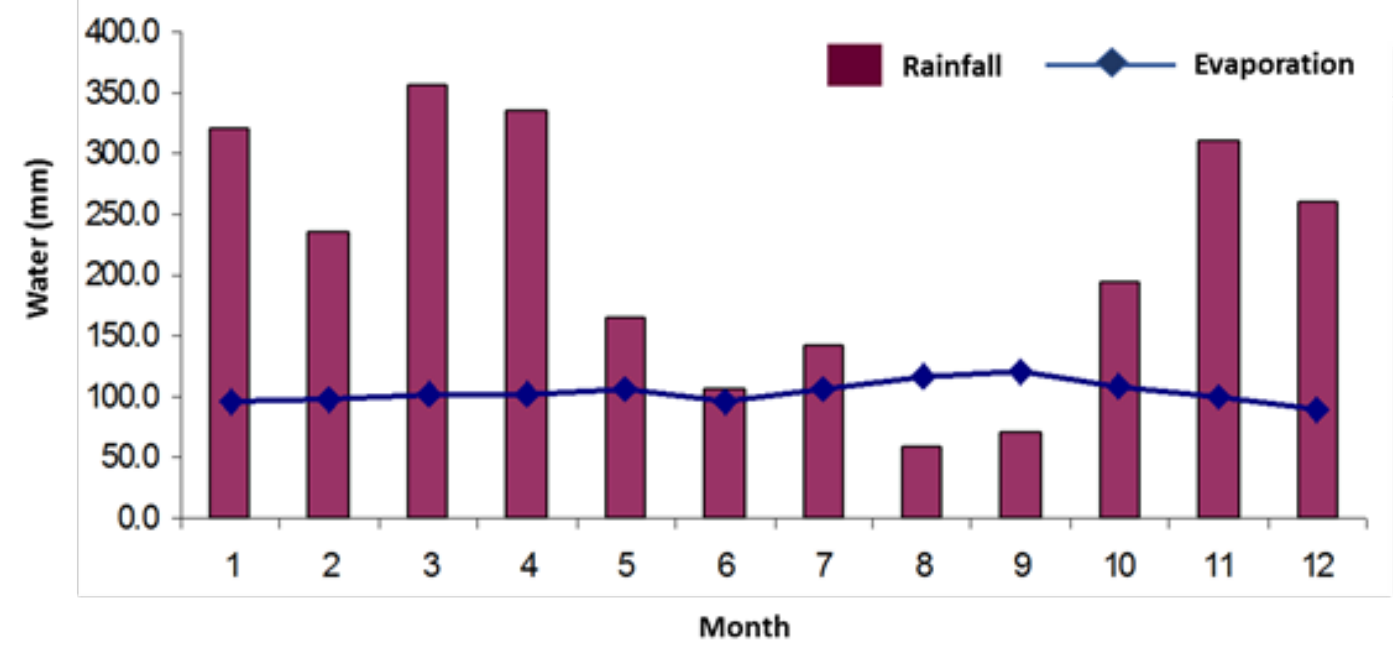

Figure 3. Relationship Between Rainfall and Monthly Potential Evapotranspiration

Illustration of the irrigation applications con- results of research of Muamar et al. (2012) which cept can be seen in Figure 2. Water is given before mentioned that the value of the average coefficient the available water runs out, usually given after in the initial, vegetative, flowering and aging phase $50-75 \%$ of available water is running out. are $1.26 ; 1.72 ; 1.66$ and 1.02 respectively. In this

The characteristics of the plant are also impor- computer simulation the root length was detertant to know to calculate the water requirement mined as long as $100 \mathrm{~cm}$. This area is the main of maize crops. The required data are the root layer in which the process of water taking occurs depth and the coefficient value of the plant (kc). through plant roots (Imanudin and Susanto, 2005). The value of coefficient of plant $(\mathrm{kc})$ refers to the 


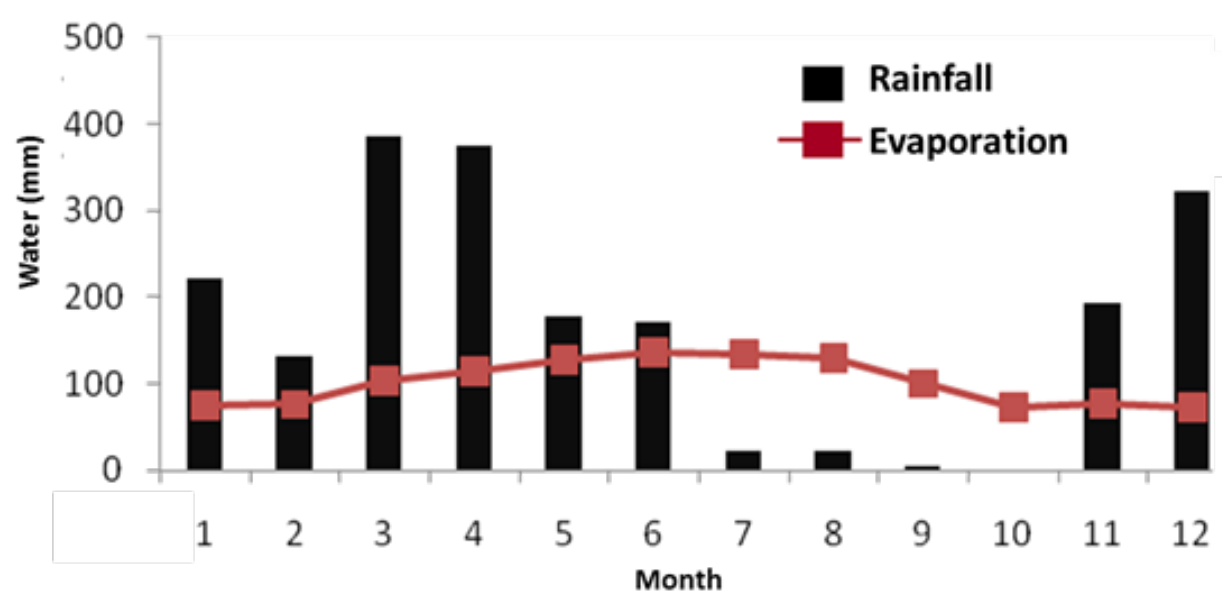

Figure 4. Relationship Between Monthly Rainfall and Potential Evapotranspiratin Under Dry Condition in 2015

\section{RESULTS AND DISCUSSIONS}

Evaluation of water avaibility

Analysis of potential evapotranspiration under normal rainfall conditions shows that the evapotranspiration value is in the range of 3.1-3.9 mm / day or in the range of $90-120 \mathrm{~mm} /$ month. Meanwhile, monthly rainfall is ranged between 57 $350 \mathrm{~mm} /$ month. There are conditions of several months where there is water shortage (water deficit) that is in August-September. Figure 3 shows the relationship between potential evapotranspiration and rainfall in 2016. Irrigation scheduling plan should have been provided if we will plant crops from May-September.

Analysis of water balance in climatic conditions experiencing the influence of El Niño phenomenon in 2015 (Figure 4) shows more dry months i.e. there are four months (July, August, September, and October). The length of the dry season was longer, so that in this condition, South Sumatra experienced extreme drought and also fire disaster. Therefore, water-efficient irrigation technology is needed in this condition, in addition to the use of mulch technology, to reduce evaporation.

\section{Irrigation Scheduling under Normal Climate Condition}

Plant irrigation should be given before the soil water level reaches permanent wilting point. This means that water is given before the available water runs out. In most plants, irrigation is applied after $75 \%$ of available water is running out. For plants that are sensitive to drought, water is given when $50 \%$ of available water is running out (Dorenbos and Pruit, 1986; Raes, 1986).

Some of the criteria needed in the irrigation scheduling system are soil moisture conditions and plant growth phases. The critical period occurs mainly in the early phases of plant growth and the start of the generative phase. The irrigation application should be concentrated on the depth of the plant parcels by calculating the depth between $0-40 \mathrm{~cm}$. Irrigation should be applied when the groundwater content is present less than $70 \%$ of the field capacity (Songhao Shang et al., 2004).

The irrigation application (each application) is done by adding water to the plant root zone (micro irrigation) (Evan et al., 1996). Irrigation is given until the entire pore space of the soil is saturated, so the frequency of irrigation will become less frequent. This condition is simpler in water management since irrigation often makes farmers face difficulties.

Computer simulation using BUDGET model was done for three scenarios of planting time i.e. maize cropping in rainy season from January to April (2016); in the transition season from 


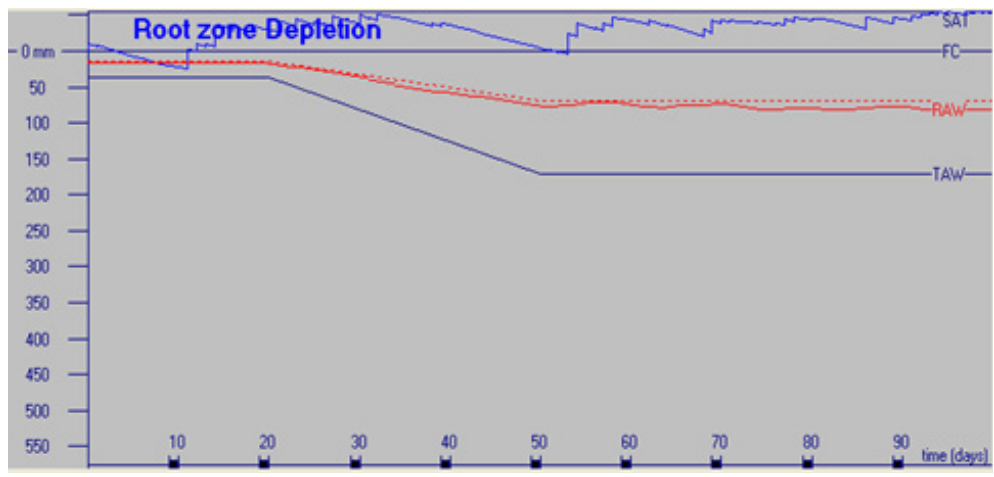

Figure 5. Analysis of Groundwater Dynamics in Rainy Season (January - April)

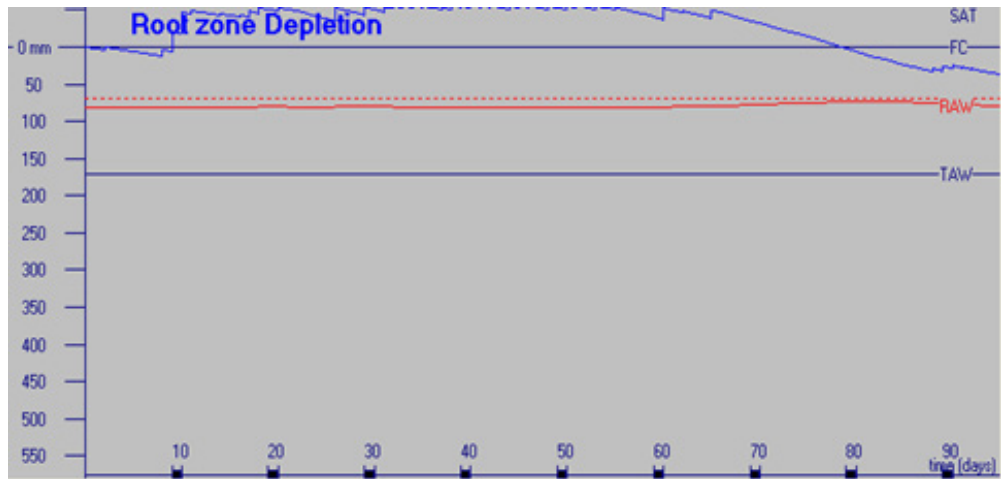

Figure 6. Analysis of Groundwater Dynamics in Transition Season (March - May)

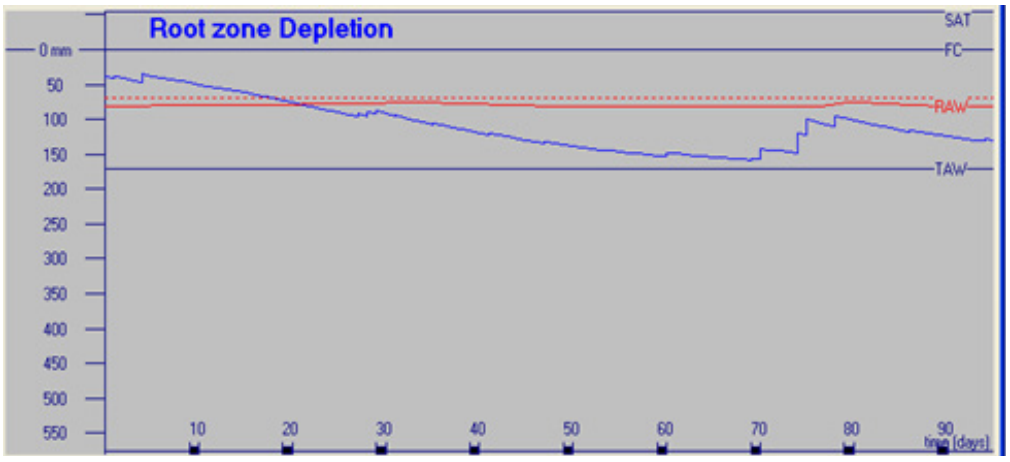

Figure 7. Analysis of Groundwater Dynamics in Early Dry Season (May - July)

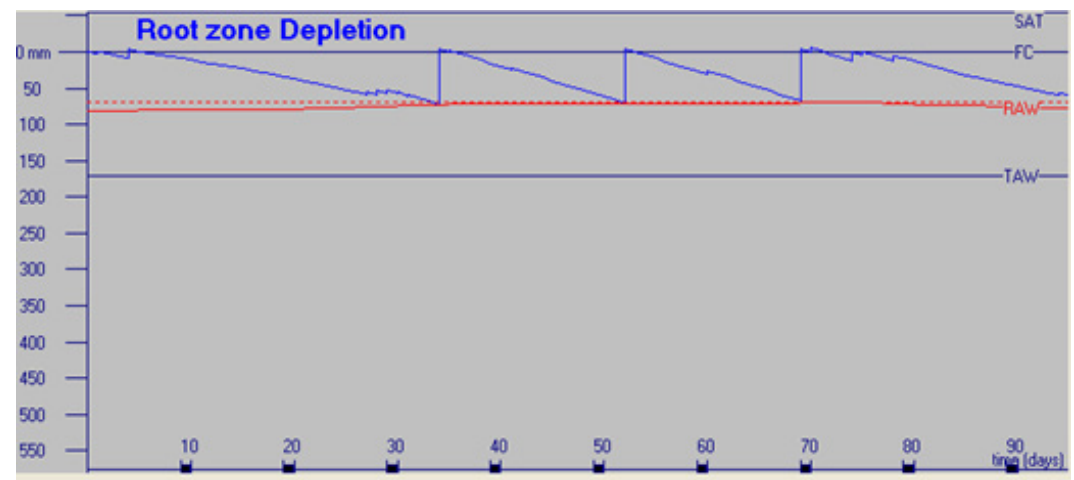

Figure 8. Condition of Groundwater Surface After Irrigation Application (May - July) 
March-May and in the dry season from May-July. Provision of water through irrigation aims to make the groundwater directly reach the field capacity conditions. The results of crop water requirement analysis show that water demand increase frequently with the development of plants (extension of the roots), and decrease when the plants begin to be harvested.

Analysis of Irrigation Application under Rainy Season Scenario (January-April)

The result of groundwater status analysis using BUDGET model in rainy season (January-April) can be seen in Figure 5. Water balance analysis shows water condition during this period is likely in saturation condition, so at this time no irrigation application is needed.

The application of water management in this period (Figure 5) acts as drainage aiming to create groundwater conditions in the field capacity. This is because saturated ground water conditions (total pore space filled with water) more than 3 days can lead to reduced oxygen in the root zone resulting in plant mortality.

Analysis of Irrigation Application under Transition Season Scenario (March-May)

Analysis of groundwater dynamics during transition season (March-May) shows the same thing as that in the rainy season. Water supply from rain is quite a lot so that the groundwater is in saturated condition. Therefore, in this period there is no need for irrigation (Figure 6).

Analysis of Irrigation Application under Early Dry Season Scenario (May-July)

Analysis of water dynamics (Figure 7), shows the status of groundwater experiencing a real decrease where in the third week the groundwater passes the critical zone (passing the available water zone). This shows that water supply from rain is not sufficient to meet evapotranspiration needs. Thus, in this season, the application of water (Irrigation) is required.

Based on Figure 7, it can be seen that the status of groundwater drops to a critical extent. This means plants need irrigation since the third week. Simulation results of water application can be seen in Figure 8. After planting in May, there is still enough rain in the early stages of growth so the plants do not need watering. The rain starts to rarely fall in the third week so the plants needs irrigation. Giving enough water is done three times every two weeks.

Analysis was then conducted under dry conditions or inside greenhouse assuming there is no rain. BUDGET computer calculation results show that maize crop water requirement in planting period when there is no rain is $321.2 \mathrm{~mm}$ (net irrigation). Under these conditions, irrigation applications are required in almost every phase of plant growth. Irrigation scheduling is performed 9 times with intervals every 7-10 days (Figure 9). This is in line with the research of Bakri and Imanudin (2012) stating that irrigation interval in the dry season with no rain requires the same application for sandy loam clay and sandy clay soil. The most influential factor is rainfall.

Based on Figure 9, it is clear that the interval of irrigation application is influenced by the growth phase of the plant and rainfall. During initial conditions, irrigation is applied every 10 days. Entering the phase of maximum growth, the crop water requirement increases so that the water supply interval is increased to every 7 days until generative growth. The water requirement decreases before the crop is ready for harvest and water is supplied every 10 days as in the initial conditions.

Soil in the study area is sandy clay soil with $47 \%$ total pore space meaning groundwater in saturated condition is $47 \%$. So the soil ability to store water 


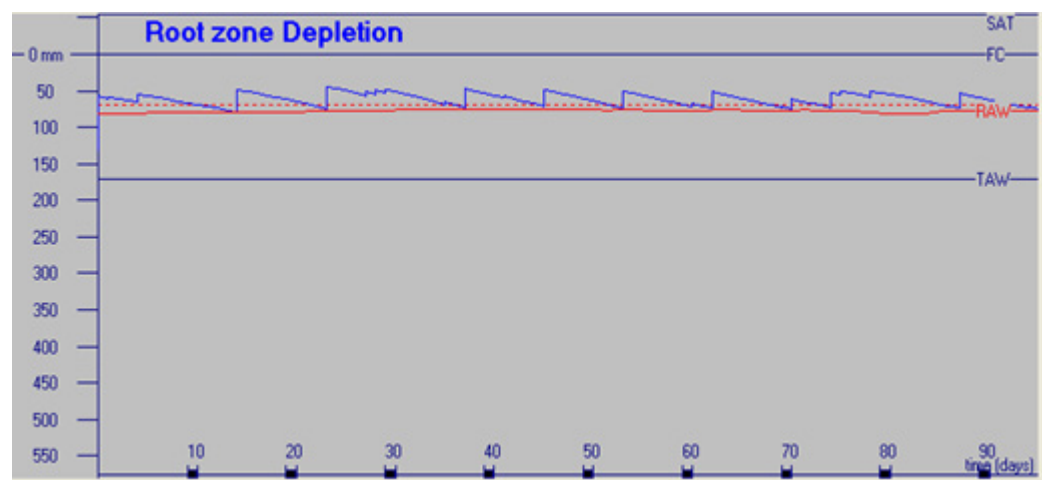

Figure 9. Groundwater Dynamics Under Irrigation Application During Planting Period (May-July)

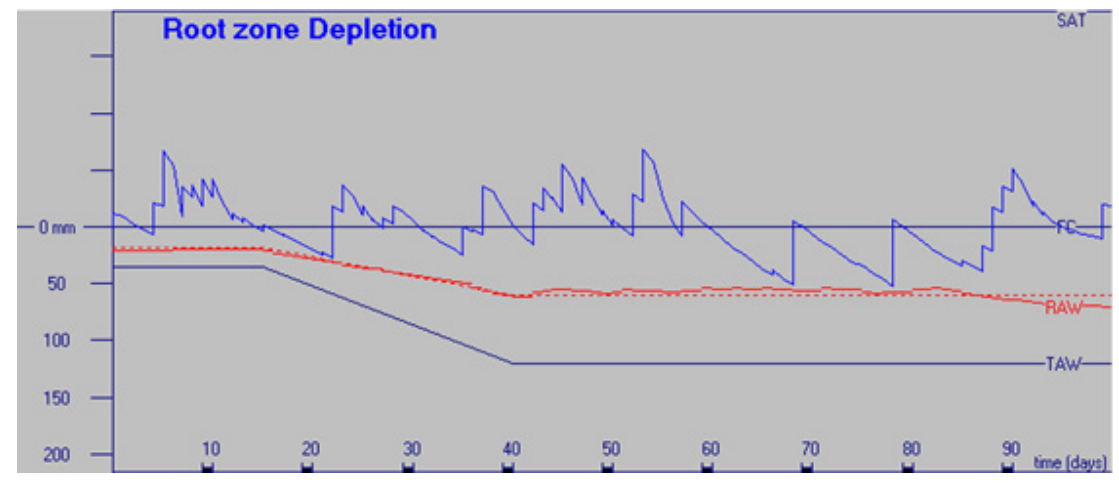

Figure 10. Irrigation simulation during March - June 2015

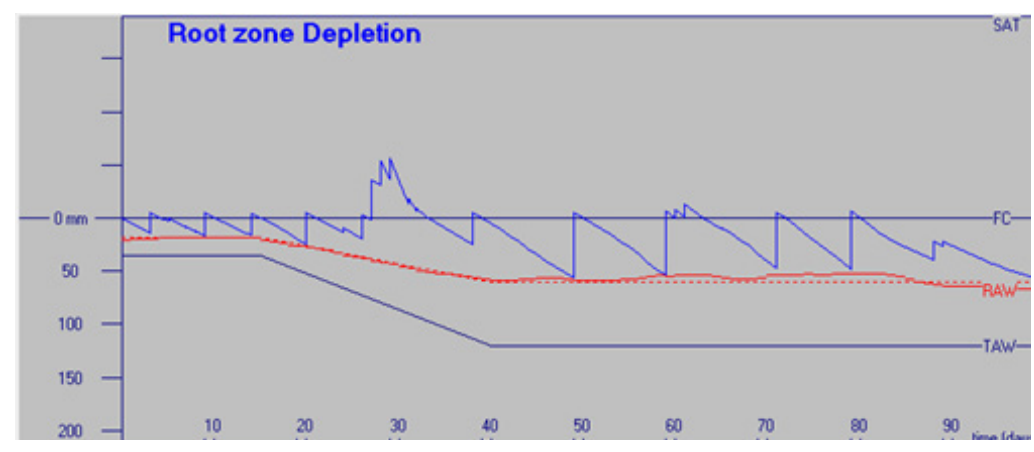

Figure 11. Irrigation scheduling simulation conducted in May - August

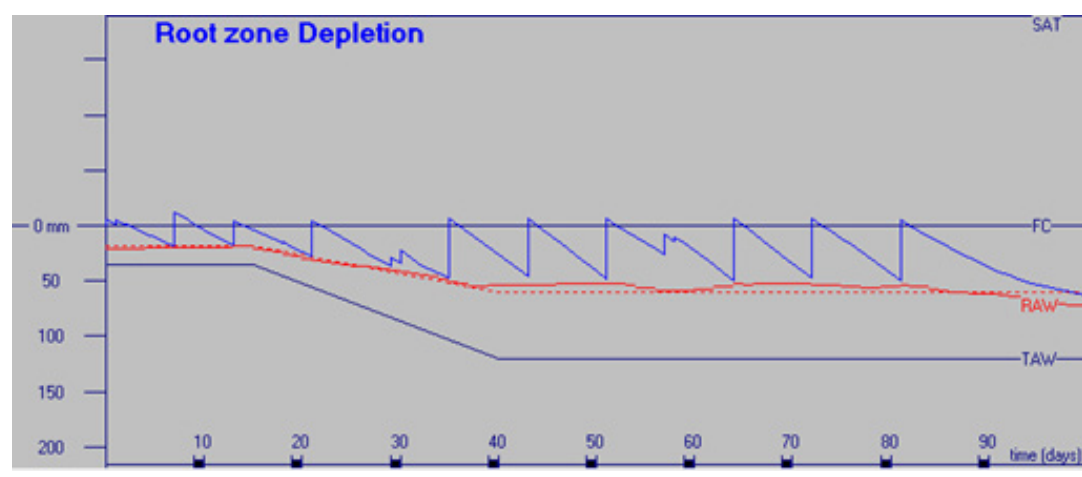

Figure 12. Irrigation scheduling simulation during June -September 
for a root depth of $20 \mathrm{~cm}$ is as much (47\% x 200 $\mathrm{mm})=94 \mathrm{~mm}$. Water supply is done to make the soil condition is in field capacity. The moisture content of the field capacity is $32 \%$, so to achieve this condition, water as much $(32 \% \times 200 \mathrm{~mm})=$ $64 \mathrm{~mm}$ is required. If irrigation has water efficiency of $75 \%$, then $80 \mathrm{~mm}$ water is needed. Thus, the volume of water required in 1 hectare is $0.08 \mathrm{~m} \mathrm{x}$ $10,000 \mathrm{~m}^{2}=800 \mathrm{~m}^{3}$ of water.

To reduce water losses from evaporation, water conservation efforts are needed. One of the most effective efforts is mulching. With mulch technology then ground water can be saved. Research on bulk irrigation using plastic mulch, irrigation water needs can be saving up to $24-26 \%$ (Ingman et al., 2015). In addition, the use of mulch is able to maintain soil moisture and temperature as well as to increase soil microbial activity (Shujing et al., 2016).

Irrigation Scheduling under Dry Climate Condition due to El Niño

Maize crops require an average water range of $423-450 \mathrm{~mm}$ in conditions without water deficit (Liu, 2002); and the amount of water provided depends on the method of irrigation and the type of soil texture. The maximum number of irrigation applications reaches $642 \mathrm{~mm}$ (Welde et al., 2016); in accordance with Ezekie (2016) mentioning a range of $432 \mathrm{~mm}$ irrigation applications. For tropical area, Muamar et al. (2012) reported that the application of irrigation water for corn crops was $614 \mathrm{~mm}$.

Budget model simulation results show that under dry climate conditions in 2015, maize crops production requires irrigation. Irrigation should be given when the crop is cultivated starting in March. It is shown that on the 20th day the plant should start to be irrigated. The planting period MarchJune requires irrigation 5 times only (Figure 10).
On the contrary, under normal climatic conditions such as the rain conditions in 2016, planting period March-June does not require irrigation.

The next trials were conducted when maize crop cultivation is done in May and ended in August (Figure 11). This condition requires farmers to prepare a good micro irrigation system because almost whole growth phases rely only on irrigation due to lack of rainfall. Irrigation is administered as much as 11-12 times, with intervals once every 4-5 days during initial phase and once every 10 days during vegetative phase. This condition requires the land area to be close to the water source, so that irrigation can be done easily. In addition, it is necessary for water conservation effort to make irrigation application can be done on time in exact amount.

Similar conditions were experienced by farmers when planting the crops in June-September (Figure 12). In this period there is no rainfall, it is even the peak of the dry season. Thus, the crops cultivation totally depends on irrigation. It can be concluded that to deal with El Niño dry climate conditions, farmers must prepare irrigation facilities since March. Watering has to be given since April. Therefore, to save water then irrigation application must be combined with mulch usage.

During initial conditions, the interval of irrigation is every 10 days. Entering the maximum growth phase, crop water requirement increases so that water supply is also increased to every 7 days until generative growth phase. The crop water requirement decreases before the crop is ready for harvest, so that the interval of irrigation is also decreased to every 10 days. This condition is in line with the research of Elzubeir and Abdelmoniem (2011) mentioning that irrigation intervals every 10 days are capable of producing the highest production of maize crops. The interval of water supply and the volume of water that can be stored in the soil are strongly influenced by rainfall and soil 
texture (Bakri and Imanudin, 2012). Under dry climate (ElNiño), water is supplied more frequently i.e. 12 times and under normal climatic conditions it is supplied only 10 times.

Irrigation application is done when $75 \%$ of the available water runs out. The soil in studied area has available water content of $30 \%$. So the irrigation application at root depth of $200 \mathrm{~mm}$ is 60 $\mathrm{mm}$. One hectare of land requires $600 \mathrm{~m}^{3}$ of water volume. This is in line with the research of Dioudis et al. (2009) mentioning that interval of water supply for maize crops is every 9 days. Therefore, the volume of irrigation water must be obtained by maximizing the use of surface water sources. When rain falls with a thickness of $50 \mathrm{~mm}$ for two days then water that can be harvested in 1 hectare is $0.1 \mathrm{~m} \times 10,000 \mathrm{~m}^{2}=1000 \mathrm{~m}^{3}$. The uneconomical pump irrigation is often used by farmers when the crops enter the flowering phase. Therefore, the arrangement of crop calendars becomes an important part in irrigation planning in dry land, especially for maize crops. High cost irrigation is only feasible for crops that have high economic value, such as chilies, strawberries etc.

\section{CONCLUSION}

The ability of BUDGET computer model is to predict the dynamics of groundwater in plant root zone, as well as to calculate the crop water requirement and determine the interval of water supply on the condition of the field in accordance with the existing rainfall conditions. Therefore, this model is well used to develop water management plan and planting schedule in dry land.

In normal climate conditions, the results of the analysis show that from rainy season planting conditions until the transition season the status of ground water reaches saturated condition in which the influence of rainfall significantly increases the ground water content. These conditions cause the land not need irrigation. Irrigation is only done when farmers do the planting in the early dry season until dry season (May-July).

In El Niño dry climate conditions, the simulation results show that irrigation applications are not needed during the crops cultivation in January. However, if the planting starts in February, irrigation should be given since mid March. Therefore, to anticipate the drought, water source and micro network system should be provided in the field. The modeling irrigation interval is 10 days, with a water volume of $600 \mathrm{~m}^{3}$ / ha and this condition is in line with the field research results from several researchers. Setting the planting schedule becomes an important part to reduce the number of irrigation applications in the field.

\section{REFERENCES}

Bakri dan Imanudin, M.S. 2012. Penggunaan BUDGET model untuk merancang irigasi kalender tanaman jagung pada tanah tekstur lempung berpasir untuk daerah iklim Palembang. Jumal Teknotan 6: 737-744.

Benoît S, L. Jérémie, and C. Pascal, 2004. Irrigation scheduling of confectionery groundnut (Arachis hypogeaea L.) in Senegal using a simple water balance model.

Agricultural Water Management Journal 67: 201-220.

Doorenbos and Pruitt. 1978 In: Raes. 1986. BUDGET: A field water balance model. Reference Manual. Faculty of Agricultural and Applied Biological Science Institute for Land and Water Management. Katholieke Universiteit Leuveun. Belgium. 34 p.

Elzubeir, O.A., and E. M. Abdelmoniem. 2011. Irrigation scheduling for maize (Zea mays L.) under desert area conditions. North of Sudan: Agriculture and Biology Journal of North America 2: 645-651 doi:10.5251/abjna.2011.2.4.645.651

Evans, R., D.K. Cassel, and R.E. Sneed. 1996. Soil, water and crop characteristics important to irrigation scheduling. Published by: North Carolina Cooperative Extension Service. Publication Number: AG 452-1. Last Electronic Revision: June1996 (KNS).

George, B. A., S.A. Shende, and N.S. Raghuwanshi. 2000. Development and testing of an irrigation scheduling model. Agricultural Water Management 46:121-136

Hillel, D. 1980. Applications of soil physics. Academic press, Inc (London) LTD, $385 \mathrm{p}$.

Ingman, M., M. V. Santelmann, and B. Tilt. 2015. Agricultural water conservation in China: plastic mulch and traditional irrigation. Ecosystem Health and Sustainability 1:12. http://dx.doi. org/10.1890/EHS14-0018.1

Imanudin, M.S. and R.H. Susanto. 2005. The use of pedotransfer function for simulating computer model (BUDGET) for analys- 
ing water balance under root zone: National Journal of Tropical Soils. 11p

Imanudin, M.S. and D. Tambas. 2002. Penentuan jumlah dan waktu pemberian air irigasi tanaman cabai melalui informasi data iklim, tanaman, dan tanah. Jurnal Agrista 12: 1410-3389.

Imanudin, M.S. R.H. Susanto, and A. Zainudi. 1997. Analisis kemampuan menahan air beberapa contoh tanah sebagai dasar perencanaan irigasi di Sumatera Selatan. ISBN No. 979-95242-0-2.

Imanudin, M.S., and R.H. Susanto. 1995. Penggunaan kurva karakteristik kelembaban tanah dan data iklim dalam perhitungan neraca air tanaman kedelai dan jagung. ISBN No: 979-95354-0-9.

Liu, C., X. Zhang., and Y. Zhang.v2002. Determination of daily evaporation and evapotranspiration of winter wheat and maize by large-scale weighing lysimeter and micro-lysimeter. Agricultural and Forest Meteorology. 111: 109-120.

Muamar, S. Triyono, A. Tusi, and B. Rosadi. 2012 Analisis neraca air tanaman jagung (Zea mays) di Bandar Lampung. Jurnal Teknik Pertanian Lampung 1: 1-10.

Raes, D. 2002. BUDGET - a soil water and salt balance model. Reference manual. Kathoilike Universiteit .Leuven, Department Land Management, Leuven, Belgium.
Shujing, Q., L. Sien, K. Shaozhong, D. Taisheng, T. Ling, and D. Risheng. 2016. Can the drip irrigation under film mulch reduce crop evapotranspiration and save water under the sufficient irrigation condition? Agricultural Water Management Journal 177: 128-137.https://doi.org/10.1016/j.agwat.2016.06.022

Songhao Shang, L. Xichun, M. Xiaomin, and L. Zhidong. 2004. Simulation of water dynamics and irrigation scheduling for winter wheat and maize in seasonal frost areas. Agricultural Water Management Journal 68: 117-133.

Yoo, S.H., Jin-Yong, J.Y. Choi, M.W. Min-Won Jang. 2008. Estimation of design water requirement using FAO Penman-Monteith and optimal probability distribution function in South Korea. Agricultural water management 95: 845 - 853.

Zotarelli, L, J. M. Scholberg, M. D. Dukes, Rafael Mun; oz-Carpena a, Jason I. 2009. Tomato yield, biomass accumulation, root distribution and irrigation water use efficiency on a sandy soil, as affected by nitrogen rate and irrigation scheduling. Agricultural water management 96: 23 - 34.

Welde, K. and L.H. Gebremariam. 2016. Effect of different furrow and plant spacing on yield and water use efficiency of maize. Agricultural Water Management. 177: 215-220. 